\title{
Comprehensive Income: How Is It Being Reported And What Are Its Effects?
}

Charles E. Jordan (Jordan@ cba.usm.edu), Univ. of Southern Mississippi Stanley J. Clark (Clark@ cba.usm.edu), Univ. of Southern Mississippi

\begin{abstract}
SFAS No. 130 allows three format choices for reporting comprehensive income (CI); two involve reporting CI in a performance-based financial statement, while the third option incorporates it into a statement of changes in stockholders' equity (SCSE). Prior research suggests that reporting $\mathrm{CI}$ in the latter option results in less useful information for investors. This study examines CI reporting for a sample of financial service firms and demonstrates that a majority (63\%) of them chose a SCSE format. In addition, a significant association existed between both the direction and size of the components of other comprehensive income and the format chosen.
\end{abstract}

\section{Introduction}

n June 1997, the FASB issued Statement of Financial Accounting Standards (SFAS) No. 130, Reporting Comprehensive Income, which requires firms presenting a full set of financial statements to report comprehensive income (CI). The standard became effective in 1998. The notion of CI is not new and was first defined by the Board in 1985 in its Conceptual Framework as "the change in equity of a business enterprise during a period from transactions and other events and circumstances from nonowner sources (FASB, 1985, para. 70)."

Several factors led the FASB to issue a standard requiring the reporting of CI. From an international perspective, the United Kingdom Accounting Standards Board issued in 1992 a standard requiring a statement of total recognized gains and losses as a second statement of income to supplement the profit and loss statement (Foster and Hall, 1996). In addition, prior to the Board issuing SFAS No. 130, it was aware that the International Accounting Standards Committee had an exposure draft outstanding that would require a second statement of income. Domestic user groups also encouraged the FASB to examine CI. For example, the Association for Investment Management and Research (AIMR) and the Robert Morris Associates (RMA), both very influential user groups, urged the FASB in the early 1990's to require the reporting of CI and its components (Beresford and Johnson, 1996).

Prior to SFAS No. 130, many gain and loss items bypassed income and were carried straight to owners' equity; the three major items included unrealized gains and losses on available-for-sale securities, foreign currency translation adjustments, and minimum pension liability adjustments. SFAS No. 130 now requires that firms with any of these three items, as well as reclassification adjustments for both unrealized gains and losses on available-forsale securities and foreign currency translation adjustments, report CI and its components. In essence, CI comprises traditional net income plus or minus these special components affecting owners' equity but not net income; these special components are commonly referred to as items of other comprehensive income (OCI). CI and its components, including net income, must be presented in a financial statement that is given equal prominence with other financial statements. The FASB allows some flexibility in reporting CI in that it may be shown in the financial statements in any of the following formats:

Readers with comments or questions are encouraged to contact the authors via email.

1. in a combined statement of net income and CI

2. in a separate statement of CI 
3. in a statement of changes in stockholders' equity

The items of OCI may be reported on either a before-tax or after-tax basis. If reported at before-tax amounts, the tax effects must be disclosed in the footnotes.

The Board believes that $\mathrm{CI}$ is a measure of financial performance and should be reported as such. Accordingly, the exposure draft on CI required that CI be presented in a separate statement of CI or in a combined statement of net income and CI. However, most respondents to the exposure draft stated that confusion would ensue by reporting two performance measures (i.e., net income and CI). Respondents noted that users would be unable to determine the appropriate performance measure to use in different decisions. As such, the FASB provided in SFAS No. 130 the third reporting option, whereby CI may be presented in a SCSE, which implies that CI is not a measure of financial performance. The Board encourages reporting CI in a statement of financial performance (i.e., one of the first two reporting options) but allows the third option.

It is this flexibility in reporting CI under SFAS No. 130 that sets the stage for the current study. For a sample of firms in the financial services industry, this study determines the relative significance or size of the items of OCI, the type of reporting format used, and the characteristics of the firms choosing specific reporting formats.

\section{Prior Research}

Essentially, three streams of literature exist in relation to CI and SFAS No. 130. First, numerous practitioner-based articles address implementation issues associated with SFAS No. 130 (e.g., de la Roza and Franz, 1997; Luecke and Meeting, 1998; Godwin and Alderman, 1999). Although not particularly relevant for the current research, the above articles provide interested readers with useful information concerning the requirements of SFAS No. 130. Second, several articles address CI from a theoretical standpoint and explain what CI is and why it should be reported (e.g., Robinson, 1991; Johnson and Reither, 1995; Beresford and Johnson, 1996; Foster and Hall, 1996; Linsmeier and Gribble, 1997a; Linsmeier and Gribble, 1997b). Even though these articles provide a good background on CI, they too are not particularly relevant for the current study, which is concerned with how CI is being reported subsequent to SFAS No. 130's issuance.

Third, and of primary importance for the current study, several empirical and survey-based articles examined the importance of CI. King et al. (1999) surveyed chief financial officers (CFOs) of publicly traded companies prior to the effective date of SFAS No. 130 to determine which of the three reporting formats the CFOs intended to use and whether the CFOs considered reporting CI useful to financial statement users. Approximately $67 \%$ of the CFOs responding stated that they preferred the option of reporting CI in a SCSE, while 33\% preferred one of the two performance-based financial statement formats. In addition, the majority of the CFOs indicated that reporting CI was either not useful $(35.90 \%)$ or actually misleading $(38.46 \%)$ to users. There was a strong correlation between the respondents preferred reporting format and their views toward the usefulness of reporting CI. Not surprisingly, respondents questioning the usefulness of reporting CI generally preferred a SCSE reporting option. King et al. (1999) also examined the relationship between the CFOs preferred reporting format and the direction (positive/negative) of the OCI items and found no association between the two. Thus, the choice of reporting format appears to be unrelated to the effect the items of OCI have on CI.

In addition to examining CFOs' beliefs and intentions, King et al. (1999) surveyed users (i.e., members of AIMR), and, although a relatively low response rate was achieved, the results were quite interesting. Contrary to CFOs, $82 \%$ of the users preferred that CI be reported in one of the two performance-based financial statements; only $18 \%$ preferred a SCSE option. Also, the form of reporting CI appeared to have an impact on whether these analysts would use $\mathrm{CI}$ in computing traditional performance measures, such as return on equity. Reporting CI in a SCSE lessened the likelihood that CI would be used in computing performance ratios. Hirst and Hopkins (1998) reached a similar conclusion in an experiment conducted with professional security analysts and portfolio managers. They examined one component of OCI, unrealized gains and losses on available-for-sale securities, and found that displaying this information in one of the two performance-based financial statements, as proposed originally in the Board's exposure draft, was effective in revealing to the professional investors a company's active earnings management 
through its marketable securities portfolio. Displaying the information in a SCSE, as allowed by SFAS No. 130, was not effective in revealing this type of active earnings management to users.

Unlike the King et al. (1999) and Hirst and Hopkins (1998) studies, which both examined the usefulness of CI reporting formats from the perspective of professional investors, Maines and McDaniel (2000) investigated this issue from the standpoint of nonprofessional investors. They conducted an experiment with individual investors, and their results show that nonprofessional investors will use CI information in evaluating management performance only if it is presented in a separate statement of CI. Thus, all three studies examining the usefulness of CI in relation to its reporting format reached similar conclusions; placement of $\mathrm{CI}$ in a performance-based versus nonperformancebased financial statement signals the importance of $\mathrm{CI}$ information to users and impacts their use of this information. Reporting CI information in a SCSE conveys to users that this information is unrelated to corporate performance; therefore, it is used little by investors.

Using data existing prior to SFAS No. 130 (i.e., 1996 data), Schmidt (1999) examined the items of OCI and determined what CI would have been for 26 of the largest U.S. companies. Similarly, Smith and Reither (1996) recast CI for ten companies in seven industries for 1995. Neither study examined the significance of the OCI items relative to the size of the firms, nor did they examine the reporting format used since the sample companies did not actually report CI.

Campbell et al. (1999) examined the actual effects of SFAS No. 130 but did so with a sample of 73 companies that adopted the standard early (i.e., in 1997). They found that 53\% of the early adopters examined reported CI in a SCSE; 47\% reported CI in one of the two performance-based financial statements. Their results also indicated that firms choosing a performance-based reporting option tended to have items of OCI that were material and positive. In contrast, firms opting for a SCSE format generally had items of OCI that were material and negative. This was an interesting result and contrary to the finding in King et al. (1999) that CFOs' decisions regarding reporting format would be unrelated to the direction of the OCI items. Campbell et al. (1999) also found that firms choosing a SCSE format tended to be larger than those opting for a performance-based format. They note that their results apply only in relation to early adopters of SFAS No. 130 as the firms in their sample were likely favorably disposed to CI. The results might be quite different for a sample of firms not adopting the standard early.

Ketz (1999) examined a nonrandom sample of 90 large firms for 1998 from numerous industries. He reported that several firms presented CI in a separate statement of CI, but that the majority reported it in a SCSE. However, he did not present the exact numbers of firms using the three reporting options. He also did not compare the characteristics of the firms using the various formats. Perhaps his primary finding, which was quite logical, was that the kind of OCI item reported was related to the industry type. For example, financial service firms primarily reported unrealized gains and losses on available-for-sale securities, while manufacturing firms had a preponderance of minimum pension liability adjustments.

\section{Research Questions}

As Hirst and Hopkins (1998) state, the FASB has indicated that it will continue to consider issues related to CI. The Board had hoped that companies would report CI in one of the two performance-based financial statement formats, even though they allowed a nonperformance-based (SCSE) option. Studies (e.g., Maines and McDaniel, 2000; King et al., 1999; Hirst and Hopkins, 1998) have shown that users likely will use the CI information much less if it is reported in a SCSE. Now that SFAS No. 130 is in effect, an important question becomes how are firms reporting CI? Another relevant question centers on how significant or material are the items of OCI? Stated differently, is CI "worth the fuss?"

Research prior to the implementation of SFAS No. 130 provides conflicting information on whether the direction of the OCI items would affect the choice of reporting format. Thus, another critical question in the current study is whether there appears to be an association between the direction or size of the items of OCI and the reporting format adopted.

Campbell et al. (1999) noted that, for their sample of early adopters, firms choosing a SCSE format tended to be larger on average than companies reporting $\mathrm{CI}$ in a performance-based format. Thus, the final question ad- 
dressed in this study examines whether an association exists between company size and the reporting format chosen.

\section{Methodology and Data Collection}

Many firms do not report CI because they do not have items of OCI. Thus, collecting data on a sample of companies from the general population of all publicly traded companies would be an inefficient and ineffective way of answering the research questions posed earlier. Instead, data were collected on companies from one industry, the financial services industry, for two reasons. First, most firms in this industry would have to report CI because of their holdings of available-for-sale securities and the resulting unrealized gains and losses on such. Second, and more importantly, Dhaliwal et al. (1999) found evidence only for firms in the financial services industry that CI is more strongly associated with returns/market value or better predicts future cash flows/income than net income. In addition, they found that the only item of OCI that improves the association between income and returns is the adjustment for available-for-sale securities, which as noted previously is the primary OCI item for financial service firms.

Data were collected for a sample of 100 randomly selected financial service firms for 1998 . The only stipulation for firm size was that all companies included be publicly traded; this allowed an analysis of the association between company size and the reporting format chosen. Data were analyzed for 1998 because this is the first year companies were required to report CI. Any relationships that existed would logically be strongest in the year of adoption. For example, if a company chose to adopt a reporting format because of the direction of the items of OCI, that direction would be known for the year of adoption only (i.e., 1998). In periods after the year of adoption, the company would be locked into its reporting format and, short of changing an accounting principle, would have to use that format regardless of the direction or size of the OCI items.

For making comparisons between companies, the firms were categorized into two groups depending on whether they chose a performance-based or a nonperformance-based reporting option. Those choosing a performance-based option included firms opting for either a separate statement of CI or a combined statement of net income and CI, while those choosing a nonperformance-based option included firms selecting a SCSE format. Medians were used as the summary measures for examining differences between the groups. Medians were used rather than means because means can be unduly influenced by a few extreme observations, especially for relatively small samples. Medians are much less influenced by these extreme values.

\section{Results}

Reporting Format Used and Significance of OCI Items

The reporting format used to present CI in 1998 by the 100 financial service firms was as follows:

Combined statement of net income and CI

Separate statement of CI

As part of SCSE

\begin{tabular}{cr} 
Number & Percent \\
\hline 12 & $12 \%$ \\
25 & $25 \%$ \\
$\underline{63}$ & $63 \%$ \\
$\underline{\underline{100}}$ &
\end{tabular}

These results are relatively consistent with the findings by King et al. (1999), where 67\% of the CFOs surveyed indicated they intended to report CI in a SCSE. In their examination of 73 early adopters of SFAS No. 130, Campbell et al. (1999) found that $47 \%$ of the firms reported CI in a performance-based financial statement. Campbell et al. (1999) speculated this percentage might be lower once the standard became effective because the early adopters likely viewed CI favorably and, thus, more of them would report it in a performance-based financial statement. This appears to be the case as only $37 \%$ of the firms in our sample chose a performance-based reporting option.

The significance of the OCI items was examined next. As noted earlier, there are multiple types of gains and losses that affect CI. However, as expected, the predominant OCI item for the firms in this sample was unrealized gains and losses on available-for-sale securities. Although data were collected on all other items as well (e.g., 
foreign currency translation adjustments), they occurred infrequently and their amounts were relatively minor. As such, all items of OCI for a company were combined for purposes of analyzing their significance.

Table 1 shows the OCI items as a percentage of income before extraordinary items. All OCI items were stated on an after-tax basis to be consistent with after-tax net income. Evaluating the significance or materiality of an item is commonly accomplished by examining its size or effect in relation to income. As noted by Holstrum and Messier (1982), even though agreement exists concerning the materiality base (i.e., income), no consensus exists concerning what percentage of income is material. In their extensive review of the empirical literature on materiality, however, Holstrum and Messier (1982) did make some generalizations regarding materiality levels. Most parties would consider as immaterial items between $0 \%$ and 5\% of net income; items greater that $10 \%$ of net income would be considered material by most groups. Items falling between 5\% and $10 \%$ of net income are in a gray area for which no consensus exists concerning materiality.

Table 1

\section{Significance of OCI Items}

\begin{tabular}{lc}
\hline $\begin{array}{l}\text { OCI as } \% \text { of } \\
\text { net income }\end{array}$ & $\begin{array}{c}\text { Number of } \\
\text { firms }\end{array}$ \\
$>100 \%$ & 5 \\
$10 \%$ to $100 \%$ & 27 \\
$5 \%$ to $10 \%$ & 9 \\
$-5 \%$ to $5 \%$ & 31 \\
$-10 \%$ to $-5 \%$ & 6 \\
$-100 \%$ to $-10 \%$ & 16 \\
$<-100 \%$ & $\underline{6}$ \\
& $\underline{\underline{100}}$
\end{tabular}

Note: Negative percentages occurred because many firms had negative total OCI.

Using these guidelines, Table 1 shows that 31 of the companies had total OCI items that would be considered immaterial by most parties (i.e., OCI to net income between $-5 \%$ to 5\%). Fifteen firms had total OCI that fell in the gray area (i.e., OCI to net income between $-10 \%$ to $-5 \%$ or $5 \%$ to $10 \%$ ). The majority of firms (54) had total OCI that would be considered material by most parties (i.e., OCI to net income less than $-10 \%$ or greater than $10 \%$ ). Eleven of these 54 firms had total OCI that exceeded (either plus or minus) $100 \%$ of net income. Taken as whole, the issue of CI clearly appears worthy of the attention paid to it by the FASB and warrants attention in the accounting literature.

\section{Direction and Size of OCI and Reporting Format}

To determine if an association exists between either the direction or size of the total OCI and the choice of reporting format, the sample was divided into two groups (i.e., those firms choosing a performance-based format versus those choosing a nonperformance-based format). Thirty-seven firms chose the former, while 63 firms chose the latter. Table 2 presents the number of firms in each group whose total OCI was negative.

The information in Table 2 clearly demonstrates that, for the sample as a whole, an association exists between the direction of total OCI for a firm and its choice of reporting format. Only $18.92 \%$ of the firms selecting a performance-based financial statement experienced negative OCIs, while $46.03 \%$ of the firms opting for a nonperformance-based financial statement incurred negative OCIs. A two-sample proportion test revealed that these proportions differed at a statistically significant level. Although this result does not prove a cause-and-effect relationship exists between the direction of total OCI and the reporting format chosen, it certainly shows that firms with negative OCIs have a higher propensity to report CI in a SCSE than do companies with positive OCIs.

Table 2

Analysis of Firms with Negative OCI 


$\begin{array}{lcccc}\begin{array}{l}\text { Reporting } \\ \text { format }\end{array} & \begin{array}{l}\text { Total number } \\ \text { of firms }\end{array} & \begin{array}{l}\text { Number of firms } \\ \text { with negative OCI }\end{array} & \begin{array}{l}\text { Proportion with } \\ \text { negative OCI }\end{array} \\ \begin{array}{l}\text { Performance-based } \\ \text { Nonperformance-based }\end{array} & 37 & 7 & 18.92 \% \\ \text { Two-sample proportion test: } & 63 & 29 & 46.03 \% \\ & \begin{array}{l}\mathrm{Z} \text { value }= \\ \text { Prob. }>\mathrm{Z}=\end{array} & 2.727 & .00639 \\ & & & \\ \end{array}$

Since there is an association between the direction of total OCI and the reporting format chosen, a relation may also exist between the relative size of total OCI and the reporting format used. It might be expected that firms reporting $\mathrm{CI}$ in a performance-based financial statement would have relatively large total OCIs, while the opposite would be expected for firms reporting $\mathrm{CI}$ in a nonperformance-based financial statement. Table 3 reports the median total OCIs for the two groups of companies (i.e., performance-based versus nonperformance-based).

Table 3 reveals that, overall, firms choosing a performance-based reporting option have larger total OCIs than firms selecting a nonperformance-based format. For example, the median total OCI for the performance-based group of $\$ 1,800,000$ exceeded that of the nonperformance-based group (i.e., $\$ 100,000$ ) at a statistically significant level. Because there is a possibility that the difference in median total OCI between the two groups might be related more to company size than to choice of reporting format, the total OCI for each firm in the two groups was normalized or adjusted for the size of the company. OCI was divided by several measures of company size (i.e., total assets, total owners' equity, and gross revenues). In each case, the median value of the normalized OCI for the performance-based group was larger, at a statistically significant level, than the corresponding median value for the nonperformance-based group. Thus, there appears to be a strong association between the relative size of a firm's total OCI and the reporting format chosen. Generally, firms with larger OCIs tend to choose a performance-based reporting format, while firms with lower OCIs seem inclined to select a nonperformance-based method of presenting CI.

\section{Firm Size and Reporting Format}

Table 4 provides a size comparison for the firms in the two reporting groups. Firm size is represented by median values for three measures (i.e., total assets, gross revenues, and total owners' equity). For each measure of size, the median value for the firms reporting CI in a SCSE (i.e., nonperformance-based option) was larger than the median value for the performance-based group. However, the differences between the medians were not statistically significant (i.e., at a .05 level).

These results differ somewhat from the Campbell et al. (1999) study of 73 early adopters; they found that firms choosing a SCSE format tended to be "much larger" (p. 19) than the firms selecting a performance-based reporting format. However, Campbell et al. (1999) evaluated means, not medians, and admitted that their SCSE group was heavily influenced by four very large companies. Had they examined medians, it is possible they would have found no significant difference in the size of the firms between the two groups.

\section{Conclusions}

This study examined the actual reporting of CI subsequent to the implementation of SFAS No. 130, and some important conclusions can be drawn from its results. The majority (63\%) of the firms in the sample reported $\mathrm{CI}$ in a SCSE. As prior research noted, reporting CI in this format results in CI information receiving less weight and being used less often by users when compared to reporting it in one of the two performance-based financial statements.

Table 3

Relative Size of Total OCI by Reporting Format Group 


\begin{tabular}{|c|c|c|c|}
\hline Measure of OCI & $\begin{array}{l}\text { Reporting } \\
\text { format }\end{array}$ & $\begin{array}{l}\text { Median } \\
\text { value }\end{array}$ & $\begin{array}{l}\text { Prob. level for } \\
\text { difference } \\
\text { between medians }\end{array}$ \\
\hline $\begin{array}{l}\text { Dollar amount } \\
\text { of OCI }\end{array}$ & $\begin{array}{l}\text { performance- } \\
\text { based }\end{array}$ & $\$ 1,800,000$ & \\
\hline $\begin{array}{l}\text { OCI to total } \\
\text { assets }\end{array}$ & $\begin{array}{l}\text { nonperformance- } \\
\text { based } \\
\text { performance- } \\
\text { based }\end{array}$ & $\begin{array}{l}\$ 100,000 \\
.1474 \%\end{array}$ & .0004 \\
\hline OCI to total & $\begin{array}{l}\text { nonperformance- } \\
\text { based } \\
\text { performance- }\end{array}$ & $.0141 \%$ & .0004 \\
\hline owners' equity & $\begin{array}{l}\text { based } \\
\text { nonperformance- }\end{array}$ & $.6387 \%$ & \\
\hline \multirow{3}{*}{$\begin{array}{l}\text { OCI to gross } \\
\text { revenues }\end{array}$} & based & $.0865 \%$ & .0056 \\
\hline & based & $.7042 \%$ & \\
\hline & $\begin{array}{l}\text { nonperformance- } \\
\text { based }\end{array}$ & $.0525 \%$ & .0650 \\
\hline
\end{tabular}

Table 4

Comparison of Firm Size by Reporting Format Group

\begin{tabular}{llll}
\hline $\begin{array}{l}\text { Measure of } \\
\text { firm size }\end{array}$ & $\begin{array}{l}\text { Reporting } \\
\text { format }\end{array}$ & $\begin{array}{l}\text { Median } \\
\text { amount } \\
\text { (mill.) }\end{array}$ & $\begin{array}{l}\text { Prob. Level } \\
\text { for difference } \\
\text { between medians }\end{array}$ \\
$\begin{array}{l}\text { performance- } \\
\text { based } \\
\text { nonperformance- } \\
\text { based } \\
\text { performance- } \\
\text { based } \\
\text { nonperformance- } \\
\text { based } \\
\text { performance- } \\
\text { based } \\
\text { nonperformance- } \\
\text { based }\end{array}$ & $\$ 1,709$ & $\$ 3,287$ & .2250 \\
Total owners' & $\$ 245.6$ & \\
\hline
\end{tabular}

In addition, a strong association exists between both the direction and size of the items of OCI and the reporting format chosen. Firms with negative or relatively small amounts of total OCI tend to choose a SCSE format, probably because this format does not relate the OCI items to financial performance of the firm. The reporting format decision, however, does not appear to be significantly related to company size.

In summary, SFAS No. 130 may not be accomplishing the goals envisioned by the FASB, which felt that $\mathrm{CI}$ is a performance measure and should be reported as such. Even worse, it appears that SFAS No. 130 is resulting in biased financial reporting as firms seem to be making their reporting format decisions based, at least partially, on the direction and/or size of the items of OCI.

\section{Suggestions for Future Research}

This study examined the reporting of CI for firms in one industry only, the financial services industry, and 
found that a strong association exists between both the direction and size of the OCI items and the reporting format chosen. The primary OCI item for these firms was unrealized gains and losses on available-for-sale securities. Future research could replicate this study in other industries where different OCI items dominate to determine whether the associations discovered in the current study transcend industry boundaries.

In addition, this study examined CI reporting in 1998, which was a relatively good year in terms of market value increases for investments in available-for-sale securities. Future research could examine CI reporting for a sample of firms in the financial services industry for a relatively good market year (e.g., 1998) and also for a relatively poor market year (e.g., 2000) to determine if firms change their method of reporting CI between years. If such changes occur, even stronger evidence would exists that SFAS No. 130 results in biased financial reporting.

\section{References}

1. Beresford, D. B. and Johnson, L. T., "Is a Second Income Statement Needed?," Journal of Accountancy, Vol. 181, No. 4, pp. 69-73, 1986.

2. Campbell, L., Crawford, D., and Franz, D., "How Companies are Complying with the Comprehensive Income Disclosure Requirements," The Ohio CPA Journal, Vol. 58, No. 1, pp. 13-20, 1999.

3. de la Rosa, D. and Franz, D. R., "Reporting Comprehensive Income in the Financial Statements," The Ohio CPA Journal, Vol. 56, No. 4, pp. 10-14, 1997.

4. Dhaliwal, D., Subramanyman, K. E., and Tresevant, R., "Is Comprehensive Income Superior to Net Income as a Measure of Firm Performance?," Journal of Accounting and Economics, Vol. 26, January, pp. 43-67, 1999.

5. Financial Accounting Standards Board, Elements of Financial Statements, Statement of Financial Accounting Concepts No. 6, Stamford, CT: FASB, 1985.

6. Financial Accounting Standards Board, Reporting Comprehensive Income, Statement of Financial Accounting Standards No. 130, Stamford, CT: FASB, 1997.

7. Foster, N. and Hall, N. L., "Reporting Comprehensive Income," The CPA Journal, Vol. 66, No. 10, pp. 16-20, 1996.

8. Godwin, N. H. and Alderman, C. W., "Avoiding the Implementation Costs of SFAS No. 130," The CPA Journal, Vol. 69, No. 6, p. 52, 1999.

9. Hirst, D. E. and Hopkins, P. E., “Comprehensive Income Reporting and Analysts' Valuation Judgments," Journal of Accounting Research, Vol. 36, Supplement, pp. 47-75, 1998.

10. Holstrum, G. and Messier, W., "A Review and Integration of Empirical Research on Materiality," Auditing: A Journal of Practice and Theory, Vol. 2, No. 1, pp. 45-63, 1982.

11. Johnson, L. T. and Reither, C. L., "Toward Reporting Comprehensive Income,” Accounting Horizons, Vol. 9, No. 4, pp. 128-138, 1995.

12. Ketz, J. E., "Comprehensive Income: What do the Numbers Disclose?," The Journal of Corporate Accounting and Finance, Vol. 10, No. 4, pp. 79-86, 1999.

13. King, T. E., Ortegren, A. K., and Reed, B. J., "An Analysis of the Impact of Alternative Financial Statement Presentations of Comprehensive Income," Academy of Accounting and Financial Studies Journal, Vol. 3, No. 1, pp. 19-42, 1999.

14. Linsmeier, T. J. and Gribble, J., “An Issues Paper on Comprehensive Income,” Accounting Horizons, Vol. 11, No. 2, pp. 120-127, 1997a.

15. Linsmeier, T. J. and Gribble, J., "Response to FASB Exposure Draft: Proposed Statement of Financial Accounting Standards-Reporting Comprehensive Income," Accounting Horizons, Vol. 11, No. 2, pp. 117-119, 1997b.

16. Luecke, R. W. and Meeting, D. T., "How Companies Report Income," Journal of Accountancy, Vol. 185, No. 5, pp. 45$51,1998$.

17. Maines, L. A. and McDaniel, L. S., "Effects of Comprehensive Income Characteristics on Nonprofessional Investors' Judgments: the Role of Financial Statement Presentation Format," Accounting Review, Vol. 75, No. 2, pp. 179-208, 2000.

18. Robinson, L. E., "The Time has Come to Report Comprehensive Income," Accounting Horizons, Vol. 5, No. 2, pp. 107113, 1991.

19. Schmidt, R. J., "The Impact of Reporting Comprehensive Income," The Ohio CPA Journal, Vol. 58, No. 1, pp. 50-52, 1999.

20. Smith, P. A. and Reither, C. L., "Comprehensive Income and the Effect of Reporting It," Financial Analyst Journal, Vol. 52, No. 6, pp. 14-19, 1996. 